\title{
Artificial inoculation methods for testing microorganisms as control agents of seed- and soil-borne Fusarium-seedling blight of maize
}

\author{
Eckhard Koch $^{1} \cdot$ Petra Zink ${ }^{1} \cdot$ Tobias Pfeiffer $^{1} \cdot$ Astrid von Galen $^{1} \cdot$ Ada Linkies $^{1} \cdot$ Jannika Drechsel $^{2} \cdot$ Tim Birr $^{2}$
}

Received: 13 May 2020 / Accepted: 19 June 2020 / Published online: 3 July 2020

(c) The Author(s) 2020

\begin{abstract}
The study describes the development and employment of plant tests based on artificial inoculation of seeds or the potting substrate for evaluating the potential of microorganisms to control seedling blight of maize caused by seed- and soil-borne fusaria. Nine strains of Fusarium were isolated from maize kernels and identified morphologically and by molecular methods as belonging to the species Fusarium verticillioides, F. subglutinans, F. cerealis, F. poae and F. proliferatum. In order to determine pathogenicity, maize kernels were inoculated by immersion in suspensions of conidia of these isolates and sown in a pasteurized substrate in seed trays. Based on plant dry weight, the isolates of $F$. verticillioides and $F$. subglutinans were more pathogenic than the other isolates. Using an isolate of $F$. subglutinans, the efficacy of a set of 25 potential fungal and bacterial antagonists was assessed using inoculation of maize kernels by placement in mixtures of the pathogen and the antagonists. The results obtained with this methodology indicate the potential of a number of different microorganisms applied as seed treatments, including some reported previously as biocontrol agents, to control seed-borne seedling blight of maize. In order to develop a method for the testing of biocontrol agents against soil-borne attack, isolates of $F$. subglutinans, $F$. cerealis and $F$ poae from maize kernels together with isolates of $F$. avenaceum, $F$. culmorum and $F$. graminearum originating from maize silage and wheat were used to artificially inoculate the potting substrate. The results showed large differences in pathogenicity, with the most aggressive isolates belonging to F. culmorum and F. graminearum.
\end{abstract}

Keywords Biocontrol $\cdot$ Seed treatment $\cdot$ Artificial inoculation $\cdot$ Microbial antagonists $\cdot$ Clonostachys $\cdot$ Chaetomium

\section{Introduction}

In order to avoid damage during germination and early crop establishment by insect pests and plant pathogens, seeds of many agricultural and horticultural crops are routinely treated before they are sown. The most common method is

Electronic supplementary material The online version of this article (https://doi.org/10.1007/s41348-020-00350-w) contains supplementary material, which is available to authorized users.

Eckhard Koch

Eckhard.Koch@Julius-Kuehn.De

1 Federal Research Centre for Cultivated Plants, Institute for Biological Control, Julius Kühn-Institut, Heinrichstr. 243, 64287 Darmstadt, Germany

2 Department of Plant Diseases and Crop Protection, Institute of Phytopathology, Faculty of Agricultural and Nutritional Science, Christian-Albrechts-University of Kiel, Hermann-Rodewald-Straße 9, 24118 Kiel, Germany seed dressing with chemical compounds having insecticidal or fungicidal activity.

Primarily driven by concern about adverse effects of chemical plant protection products on humans and the environment, efforts have been made in recent decades to replace chemical seed treatments by environmentally more friendly methods. The alternatives available so far include physical methods, the use of living bacteria or fungi and natural compounds from plants and microorganisms (Mancini and Romanazzi 2014; Koch and Roberts 2014; O`Callaghan 2016). With the continuing call by the public, consumers and authorities for a reduction in chemical pesticide use on the one hand, and discontinuation of authorisations for chemical active ingredients on the other, along with a lack of new registrations, it can be expected that non-chemical seed treatments will gain importance in the future. However, non-chemical seed treatments are still not available in many economically important crops, necessitating further research in this field. 
In maize, fungicidal seed treatments are primarily applied to control pathogenic fungi of the genus Fusarium, which can be both seed- and soil-borne (Munkvold and White 2016). Generally, the relative importance of soil-borne versus seed-borne infections by fusaria in maize is unknown and may vary depending on site, weather conditions and seed quality. It is therefore imperative that fungicidal seed treatments control both routes of infection. Screening and development of new seed treatment agents should preferably be performed under conditions resembling the practical conditions of use. Consequently, the activity against seed-borne pathogens should ideally be assessed using naturally infested seeds. However, if infested seed lots are not available or vary in characters that affect the outcome of the experiment, such as degree of infection and composition and localization of the pathogens, the seeds can be artificially inoculated. Depending on the pathosystem, the inoculum generally consists of dry spores (like in Tilletia caries) or, more commonly, spore suspensions (e.g., suspensions of conidia). Artificial inoculation is frequently used for seed treatment trials with certain bunts and smuts of small grain cereals (Nielsen 1976; Nagy and Moldovan 2007). It has also been employed with other pathogenic fungi, including fusaria, for evaluating the effect of seed treatments (Galperin et al. 2003; Bressan and Figueiredo 2005) as well as in the context of epidemiology (Moussart et al. 1998), characterization of pathogenicity (Imathiu et al. 2010) and identification of resistant germ plasm (Bacon et al. 1994; Browne and Cooke 2005; Maitlo et al. 2016). In most studies, seed inoculation with fusaria has been performed by immersion of seeds in conidial suspensions or by spraying the conidial suspensions over the seeds (Bacon and Hinton 1996). Before inoculation, the seed surface should be disinfected or the seeds subjected to a heat treatment in order to remove internal seed-borne microorganisms (Bacon et al. 1994; Galperin et al. 2003).

Efficacy testing of seed treatments against soil-borne fusaria is generally done using artificial inoculation of the soil or potting substrate. Commonly, the pathogen inoculum consists of pre-colonized substrates such as intact or milled cereals or mixtures of the latter with sand that are evenly mixed with the soil or potting substrate (Mao et al. 1998) or applied as a layer on the top (Pandey et al. 2001; Munkvold and O`Mara 2002). Alternatively, conidial suspensions of the pathogen have been applied to the potting medium (Bacon and Hinton 2007). The advantage of artificial inoculation compared to the use of field soil is the opportunity to employ known pathogen strains and to vary the infection pressure by adjusting the inoculum concentration (Mao et al. 1998; Maitlo et al. 2016). This, however, requires pre-tests defining the test conditions, especially with regard to the pathogenicity of the Fusarium strains in question.

The aim of the present work was to establish model tests for evaluating bacteria and fungi as seed treatments against seed- and soil-borne fusaria on maize. For this purpose, the ability of different fusaria to cause seedling blight was determined under controlled conditions in tests with artificial inoculation of the seeds or artificial inoculation of the potting substrate, respectively. The test conditions were optimized, and the efficacy of a set of 25 bacterial and fungal strains against seed-borne fusaria was evaluated by co-inoculating maize kernels with an isolate of $F$. subglutinans and the putative control agents. Under the conditions employed, treatment with the majority of strains improved seedling development compared to the controls (= seed inoculation with the pathogen only), indicating that they may have potential for use as seed treatments.

\section{Materials and methods}

\section{Fusaria}

The isolates of Fusarium employed were obtained from the culture collection of Kiel University originating from maize silage ( $F$. graminearum $\mathrm{Ck} 3, F$. graminearum $\mathrm{Os} 12$, $F$. culmorum $\mathrm{Fu} 13, F$. avenaceum $\mathrm{To} 8$ ) and wheat kernels (F. culmorum VIII18). In addition, new isolates were freshly isolated from maize kernels. For this purpose, maize kernels were surface disinfected by immersion for $10 \mathrm{~min}$ in $\mathrm{NaOCl}$ $(1 \%)$, washed in sterile distilled water, placed on moist filter paper and incubated at room temperature for 3-7 days. Mycelia growing from the kernels were removed with a needle and streaked on PDA. Pure cultures were established from isolates suspected to be fusaria and stored in a freezer at $80^{\circ} \mathrm{C}$ until use.

Species determination was carried out based on morphology after culturing on SNA (Leslie and Summerell 2006) and molecularly by using universal and species-specific marker genes. DNA was extracted with the DNeasy Plant Mini Kit(Quiagen) for PCR amplification of the universal marker genes for elongation factor 1 alpha (TEF-1 $\alpha)$ and ITS-5f and ITS-4r (White et al. 1990). Mycelium was carefully removed from PDA cultures and homogenized with a FastPrep- $24{ }^{\circledR}$ Tissue and Cell Homogenizer (MP Biomedicals, USA) using Lysing Matrix A and a run time of $20 \mathrm{~s}$ with an intensity of $4 \mathrm{~m} / \mathrm{sec}$. Thereafter, the extraction kit protocol was followed. The amount and purity of the gDNA samples were determined using the NanoDrop 2000c (Thermosientific, USA), reaching an average of about $100 \mathrm{ng} / \mu \mathrm{l}$ per sample. For the PCR reactions, the Phusion HighFidelety Polymerase (NewEnglandBiolabs, USA) was used with an annealing temperature of $68{ }^{\circ} \mathrm{C}$ and 40 cycles. Microsynth SEQLAB (Germany) performed the sequencing according to Sanger. The sequences were analyzed by comparison with similar sequences in the NCBI database. 
For molecular species determination with species-specific primers, DNA was extracted using the CTAB method. Mycelial tissue, $50 \mu \mathrm{g}$, was ground in a mill and incubated in CTAB buffer for $1 \mathrm{~h}$ at $65^{\circ} \mathrm{C}$. RNAse $\mathrm{A}, 2 \mu \mathrm{l}$, was added and samples were incubated at $37^{\circ} \mathrm{C}$ for $30 \mathrm{~min}$. Five hundred microliters of chloroform-isoamylalcohol $(24+1)$ were added and samples were shaken vigorously for $10 \mathrm{~min}$ and centrifuged at 14,000 rpm for $10 \mathrm{~min}$. The upper phase was carefully transferred to a new tube and extracted with $700 \mu \mathrm{l}$ isopropanol. Samples were incubated on ice for $30 \mathrm{~min}$, centrifuged and the pellet was cleaned twice with a) $\mathrm{EtOH} 76 \%$, NA-acetate $0.2 \mathrm{M}$ and b) EtOH 76\%, Na- acetate $10 \mathrm{mM}$. The pellet was dried and dissolved in water. The following species-specific primers were used: JIA-F and JIA-R ( $F$. avenaceum; Turner et al. 1998), $\mathrm{Fc} 01-\mathrm{F}$ and $\mathrm{Fc} 01-\mathrm{R}$ (F. culmorum; Nicholson et al. 1998), Fg16-F and
Fg16-R (F. graminearum; Nicholson et al. 1998), CLOX-F and CLOX-R (F. oxysporum; Mulè et al. 2004b), Fp82-f and Fp82R (F. poae; Parry and Nicholson 1996), PRO-1-F and PRO-2-R (F. proliferatum; Mulè et al. 2004a), SUB1 and SUB2 (F. subglutinans; Mulè et al. 2004a), and VERT-1-F and VERT-2-R (F. verticillioides; Patiño et al. 2004).

\section{Potential antagonists}

The microorganisms tested for activity against seed-inoculated $F$. subglutinans were taken from the culture collection of the Julius Kühn-Institut (Institute for Biological Control) or supplied by co-operating scientists. About one-third of the tested microorganisms had a previous record as antagonists of plant pathogens (Table 1).

Table 1 Antagonistic bacteria and fungi tested against seed-inoculated $F$. subglutinans (I)

\begin{tabular}{|c|c|c|}
\hline Strain & substrate/source/supplier & Reported antagonistic activity (reference) \\
\hline Clonostachys rosea IK 726 & $\begin{array}{l}\text { Swedish Agricultural University Uppsala/Dr. } \\
\text { D.F. Jensen }\end{array}$ & $\begin{array}{l}\text { Fusarium culmorum, Alternaria sp., others } \\
\text { (Jensen et al. 2007) }\end{array}$ \\
\hline Clonostachys rosea $\mathrm{f}$. catenulata HJS 1881 & $\begin{array}{l}\text { Soil/Agricultural Institute of Slovenia/Dr. H. } \\
\text { Schroers }\end{array}$ & - \\
\hline Clonostachys sp. & Plant litter/Institute collection & - \\
\hline $\begin{array}{l}\text { Fusarium oxysporum MSA } 35 \text { (non-patho- } \\
\text { genic) }\end{array}$ & $\begin{array}{l}\text { Suppressive soil/Agroinnova, University of } \\
\text { Torino/Dr. F. Tinivella }\end{array}$ & F. oxysporum (Gilardi et al. 2005) \\
\hline Fusarium solani BBA 64531 & Pea/JKI culture collection/Dr. W. Maier & - \\
\hline Persiciospora moreaui 55 & $\begin{array}{l}\text { Asparagus/Humboldt University (Berlin)/Dr. } \\
\text { Monika Gossmann }\end{array}$ & $\begin{array}{l}\text { F. oxysporum, F. proliferatum (Hörmann et al. } \\
2010 \text { ) }\end{array}$ \\
\hline Pseudomonas chlororaphis MA 342 & $\begin{array}{l}\text { Commercial product } \text { Cerall }^{\circledR} \text { (Bioagri, Swe- } \\
\text { den; registered for control of } T \text {. caries and } \\
\text { F. culmorum) }\end{array}$ & $\begin{array}{l}\text { Pyrenophora graminea, Drechslera teres, Til- } \\
\text { letia caries (Johnsson et al. 1998) }\end{array}$ \\
\hline $\begin{array}{l}\text { Lysobacter enzymogenes } \mathrm{U} 407 \\
\text { Pseudomonas putida E } 183 \text { Pseudomonas sp. } \\
\text { IV298 }\end{array}$ & Cabbage roots/Institute collection & Pythium ultimum (Koch 1997) \\
\hline $\begin{array}{l}\text { Pseudomonas sp. I 112, Lysobacter enzymo- } \\
\text { genes U410 (DSM No. 10690) }\end{array}$ & Cabbage roots/Institute collection & $\begin{array}{l}\text { P. ultimum, Rhizoctonia solani, Phytophthora } \\
\text { fragariae (Koch et al. 1998) }\end{array}$ \\
\hline Streptomyces antimycoticus FZB53 & Abitep GmbH (Berlin)/Dr. H. Junge & $\begin{array}{l}\text { F. culmorum, T. caries, P. graminea (Koch and } \\
\text { Löffler 2009) }\end{array}$ \\
\hline $\begin{array}{l}\text { Trichoderma asperellum T23; Trichoderma } \\
\text { harzianum T16 }\end{array}$ & University of Hohenheim/Dr. A. El-Hasan & F. graminearum (El-Hasan et al. 2018) \\
\hline Trichoderma sp. & Maize roots/Institute collection & - \\
\hline Trichoderma viride BBA 69039 & Soil/JKI culture collection/Dr. W. Maier & - \\
\hline Chaetomium globosum (I) (BBA 62109) & $\begin{array}{l}\text { Horse radish/JKI culture collection/Dr. W. } \\
\text { Maier }\end{array}$ & - \\
\hline Chaetomium cochliodes (III) (BBA 63353) & $\begin{array}{l}\text { Abies; Rhododendron Forest/JKI culture col- } \\
\text { lection/Dr. W. Maier }\end{array}$ & - \\
\hline Chaetomium aureum (BBA 63132) & Guzmania/JKI culture collection/Dr. W. Maier & - \\
\hline Chaetomium nozdrenkoae (BBA 62111) & $\begin{array}{l}\text { Soil (Lolium multiflorum)/JKI culture collec- } \\
\text { tion/Dr. W. Maier }\end{array}$ & - \\
\hline $\begin{array}{l}\text { Chaetomium ramosissimum (previously: } C \text {. } \\
\text { indicum; BBA 63377) }\end{array}$ & $\begin{array}{l}\text { Abies; Rhododendron Forest/JKI culture col- } \\
\text { lection/Dr. W. Maier }\end{array}$ & - \\
\hline Chaetomium elatum (BBA70564) & $\begin{array}{l}\text { Oil painting/JKI culture collection/Dr. W. } \\
\text { Maier }\end{array}$ & - \\
\hline
\end{tabular}




\section{Preparation of Fusarium inoculum and application to seeds}

For the preparation of pathogen inoculum, the fusaria were cultured on potato dextrose agar (PDA; Sigma-Aldrich, Taufkirchen, Germany). Plates with sporulating cultures were flooded with $10 \mathrm{ml}$ sterile distilled water $(0.0125 \%$ Tween ${ }^{\circledR}$ 80; Sigma-Aldrich, Taufkirchen, Germany) and conidia were dislodged by gently scraping the colony surface with a spatula. The suspensions were filtered through cotton gauze (Mullro ${ }^{\circledR}$ ) to remove mycelial fragments, and spore concentrations were determined with a hemocytometer. Depending on the amount of spores present, the concentration of the resulting suspensions was adjusted to $1 \times 10^{5}($ F. cerealis $), 1 \times 10^{6}(F$. poae $)$ or $1 \times 10^{7}$ (all other fusaria) conidia per ml. Methyl cellulose (1\%) was routinely added to all conidial or bacterial suspensions used for seed inoculation.

In the experiment investigating the effect of the spore load, the concentration of microconidia of $F$. verticilliodes (I) in the inoculum suspension was adjusted to $1 \times 10^{5}$, $1 \times 10^{6}, 1 \times 10^{7}$ or $1 \times 10^{8}$ per ml. Maize kernels (Zea mays cv. "Padrino") were disinfected as described above and inoculated by placement of 100 kernels each for $10 \mathrm{~min}$ in $50 \mathrm{ml}$ of the conidial suspensions of the pathogens. The kernels were then dried overnight in a laminar flow hood and sown the next day, except in one experiment where only half of the inoculated kernels were sown the following day and the other half were kept in a paper bag for 80 days in a refrigerator before they were sown.

\section{Preparation of antagonist inoculum and application to seeds}

Putative microbial antagonists were applied in mixtures with conidial suspensions of the pathogen $F$. subglutinans (I). Inocula of the antagonists were prepared from cells or spores freshly raised on Petri plates or in shake cultures, except for $P$. chlororaphis MA342 which was applied using the commercial formulation Cerall ${ }^{\circledR}$. Streptomyces antimycoticus FZB 53 was grown for 3 weeks in Petri plates on potato medium (Koch and Löffler 2009), all other bacterial antagonists were cultured for $48 \mathrm{~h}$ on a rotary shaker at $25^{\circ} \mathrm{C}$ in Tryptic Soy Broth (Carl Roth, Karlsruhe, Germany). Aliquots of the shake cultures or the product Cerall ${ }^{\circledR}$ were added to conidial suspensions of $F$. subglutinans (I) (concentration $1 \times 10^{8} /$ microconidia per $\mathrm{ml}$; prepared as described above) in the ratio of $1: 10$, resulting in a final concentration of $1 \times 10^{7}$ microconidia per $\mathrm{ml}$. The putative fungal antagonists were grown in Petri plates $(9 \mathrm{~cm}$ diameter) on PDA. To sporulating fungal cultures and sporulating plates of the actinomycete $S$. antimycoticus FZB 53, $10 \mathrm{ml}$ sterile distilled water $\left(0,0125 \%\right.$ Tween $\left.80^{\circledR}\right)$ were added.
Spore suspensions were then prepared, and 1:10 dilutions with the Fusarium inoculum made, as described above. The resulting final spore concentration in the inoculum suspension of the fungal antagonists was $1-3 \times 10^{7}$ conidia per ml, except for $F$. solani where it was $3 \times 10^{6}$ conidia per $\mathrm{ml}$ and P. moreaui $\left(1 \times 10^{6}\right.$ ascospores per $\left.\mathrm{ml}\right)$. Disinfected maize kernels (Zea mays cv. "Padrino") were placed for $10 \mathrm{~min}$ in the antagonist-pathogen mixtures described, dried overnight under a laminar flow and sown the following day. The pathogen controls were seeds placed in suspensions containing only conidia of $F$. subglutinans $(\mathrm{I})\left(1 \times 10^{7}\right.$ conidia per $\mathrm{ml}$ ). The chemical seed treatment fungicide Maxim XL ( $25 \mathrm{~g} / \mathrm{l}$ fludioxonil, $10 \mathrm{~g} / \mathrm{l}$ metalaxyl-M) was used according to the recommendations of the manufacturer. It was applied on inoculated, dried seeds of the pathogen controls one day after inoculation.

\section{Preparation of Fusarium inoculum for soil application}

Fusarium isolates were grown on millet seeds, buckwheat, or pearl barley (all food grade). Conidial suspensions were prepared as described above, adjusted to $1 \times 10^{5}$ per $\mathrm{ml}$ and diluted with sterile water 1:6. The suspensions obtained were added to $100 \mathrm{~g}$ autoclaved millet seeds, buckwheat or pearl barley, respectively, in 1-1 Erlenmeyer flasks at a rate of $30 \mathrm{ml}$ per flask. The flasks were incubated in darkness at $20^{\circ} \mathrm{C}$ for $72 \mathrm{~h}$ and agitated once a day to prevent the formation of clots.

\section{Growth room trials}

Horticultural substrate (Fruhstorfer Erde Typ P; Hawita Gruppe GmbH, Vechta, Germany) was mixed with sand (60:40, [w/w]), incubated for $48 \mathrm{~h}$ at $60^{\circ} \mathrm{C}$, and after cooling adjusted to a gravimetric water content of 0.45 . In the experiments with inoculated seeds, the potting substrate was filled in $27.5 \times 17.5 \times 7 \mathrm{~cm}$ household polypropylene containers ("seed trays") with 2-4 seed trays per treatment. Twenty-five maize seeds were sown per seed tray and inoculated with fusaria or a mixture of fusaria and microbial antagonists as described above.

Potting substrate inoculated with fusaria was prepared by carefully mixing the colonized millet, buckwheat or pearl barley-inoculum described above into the potting substrate at concentrations of 1 or $3 \%(\mathrm{w} / \mathrm{w})$. The experiments with inoculated potting substrate were performed in $10 \times 10 \mathrm{~cm}$ plastic pots. Per treatment, 3-5 pots with 6 maize seeds (cv. "Emmy") each were employed.

After sowing, the seed trays/pots were covered with a layer (approx. $1 \mathrm{~cm}$ thick) of vermiculite and their weight was recorded before they were placed in a plant growth room under $16 \mathrm{~h}$ of light from fluorescent lamps at $20^{\circ} \mathrm{C}$. 
During the course of the experiment, the seed trays/pots were watered according to weight. Two weeks after planting the number of plants per seed tray/pot was recorded, plants were cut at the crown, and their dry weight was recorded after incubation for $48 \mathrm{~h}$ at $80^{\circ} \mathrm{C}$. The results are presented as number of plants or plant dry weight per seed tray or pot, respectively.

\section{Statistical analysis}

In all growth room experiments pots were arranged in a randomized design. Data were analyzed applying one-way ANOVA using the statistical software "R". Homogeneity of variances was asserted using Levene's Test $(p \leq 0.05)$. The Tukey test was used for comparisons between treatments. A $p \leq 0.05$ significance level was used throughout.

\section{Results}

PCR sequencing, species-specific primers and morphological characters were used to identify fusaria from surfacedisinfected maize kernels. Of the eight isolates studied, two were identified as $F$. verticillioides (F. verticillioides [I], $F$. verticillioides [II]), three as $F$. subglutinans (F. subglutinans [I], F. subglutinans [II], F. subglutinans [III]), and one each as F. cerealis, F. proliferatum and F. poae, respectively.

The pathogenicity of the isolates was evaluated in two independent experiments under identical experimental conditions with seeds artificially inoculated by immersion in conidial suspensions. In both experiments, inoculation of the maize kernels had no or only a small effect on plant stand. Only inoculation with $F$. subglutinans (I) caused a significant reduction in the number of plants per seed tray by $10-20 \%$ in both experiments (Fig. 1). More significant differences were observed in the plant dry weight. Both isolates of $F$. verticillioides and isolate $F$. subglutinans (I) reduced the plant dry weight by around $50-60 \%$. The isolates $F$. subglutinans (II), $F$. subglutinans (III) and $F$. cerealis were intermediate in pathogenicity, whereas $F$. proliferatum and $F$. poae had no effect or were only mildly pathogenic (Fig. 2).

The differential impact on plant stand as compared to plant biomass was also seen in the second set of experiments. Again, plant biomass was more affected than plant number (Figs. 3 and 4). Inoculation with $10^{7}$ conidia per $\mathrm{ml}$ of $F$. subglutinans (I) or F. subglutinans (II) and $10^{7}$ and $10^{8}$ conidia per $\mathrm{ml}$ of $F$. verticillioides (I) significantly reduced the plant biomass. Inoculation with conidial concentrations of $10^{5}$ and $10^{6}$ per $\mathrm{ml}$ of $F$. verticillioides (I) also caused a reduction in plant biomass that was statistically significant only in one case.

After sowing of seeds that had been stored after inoculation for 80 days at $4{ }^{\circ} \mathrm{C}$, the plant biomass was similarly reduced as in the case of plants grown from seeds sown 1 day after inoculation (Fig. 5), indicating that storage of inoculated seeds had no adverse effect on the virulence of the inoculum. This also implies that in such trials a stock of inoculated seeds can be prepared in advance for use in several experiments.

In the experiments evaluating the potential of microorganisms to protect against seed-borne $F$. subglutinans (I), inoculation of maize seed with the pathogen only reduced the biomass of the seedlings growing from this seed by about $30 \%$ (Fig. 6). No reduction was recorded after seed treatment with the chemical fungicide Maxim XL and some of the tested microorganisms. Among the latter, the level of control was highest by the necrotrophic mycoparasite Clonostachys rosea IK726. Strain Clonostachys
Fig. 1 Effect of seed inoculation with conidia of different isolates of Fusarium on number of maize seedlings (Means of 2 individual experiments, each with 4 seed trays per treatment and 25 seeds per tray; determined 14 days after sowing). Different letters above bars indicate statistically significant differences between treatments within the experiments $(p \leq 0.05)$

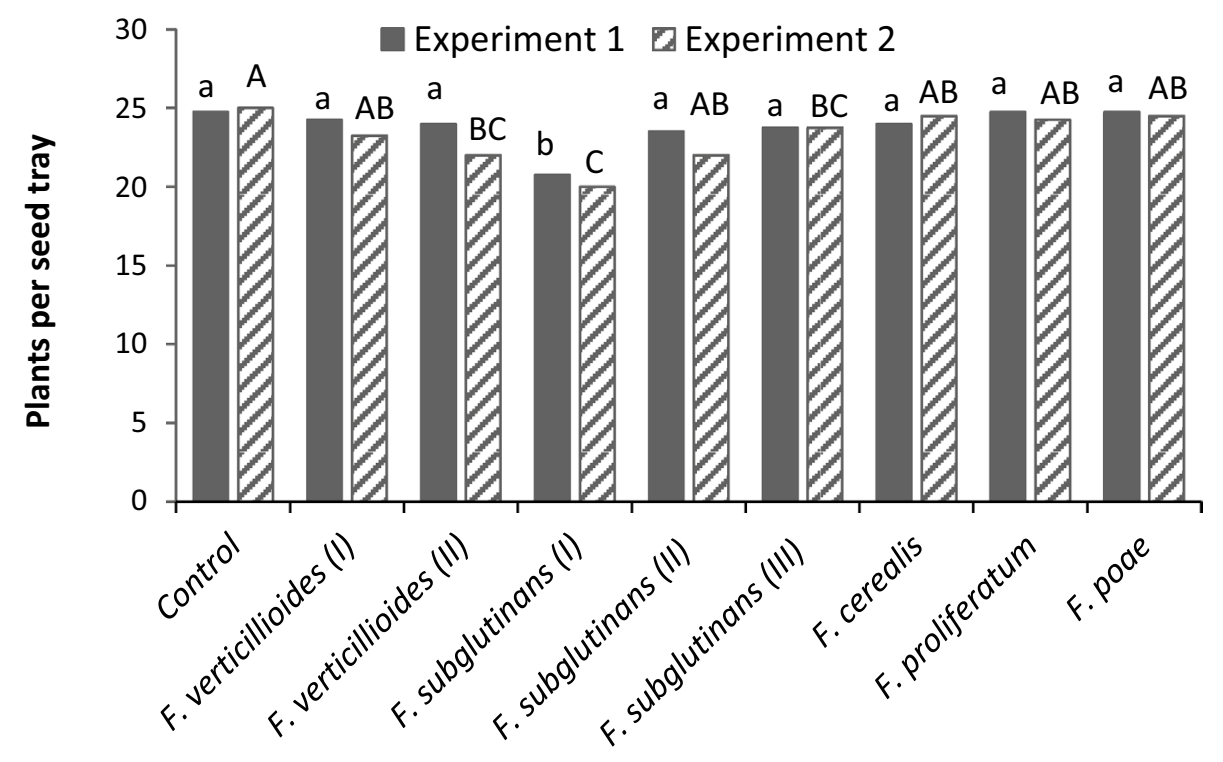


Fig. 2 Effect of seed inoculation with conidia of different isolates of Fusarium on biomass of maize seedlings (Means of 2 individual experiments, each with 4 seed trays per treatment and 25 seeds per tray; determined 14 days after sowing). Different letters above bars indicate statistically significant differences between treatments within the experiments $(p \leq 0.05)$

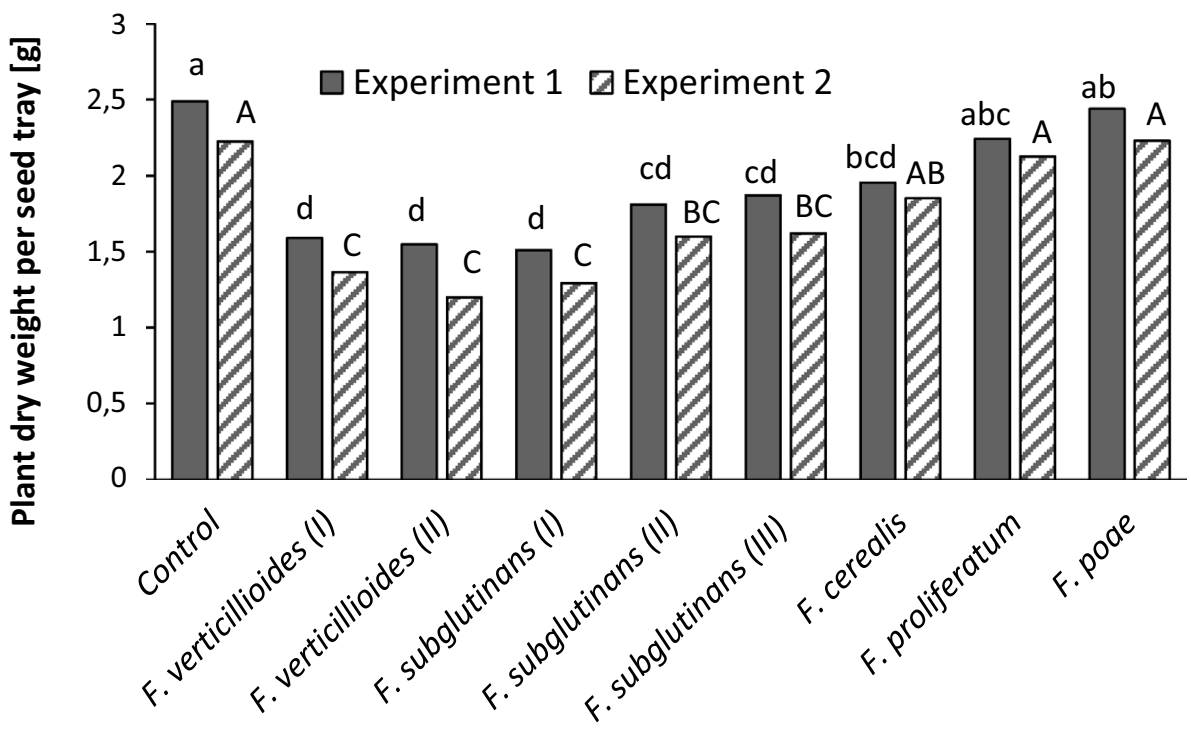

Fig. 3 Effect of seed inoculation with different concentrations of conidial suspensions of Fusarium verticillioides (I) and two isolates of $F$. subglutinans $\left(1 \times 10^{7}\right.$ conidia per $\left.\mathrm{ml}\right)$ on number of maize seedlings (Means of 2 individual experiments, each with 4 seed trays per treatment and 25 seeds per tray; determined 14 days after sowing). Different letters above bars indicate statistically significant differences between treatments within the experiments $(p \leq 0.05)$

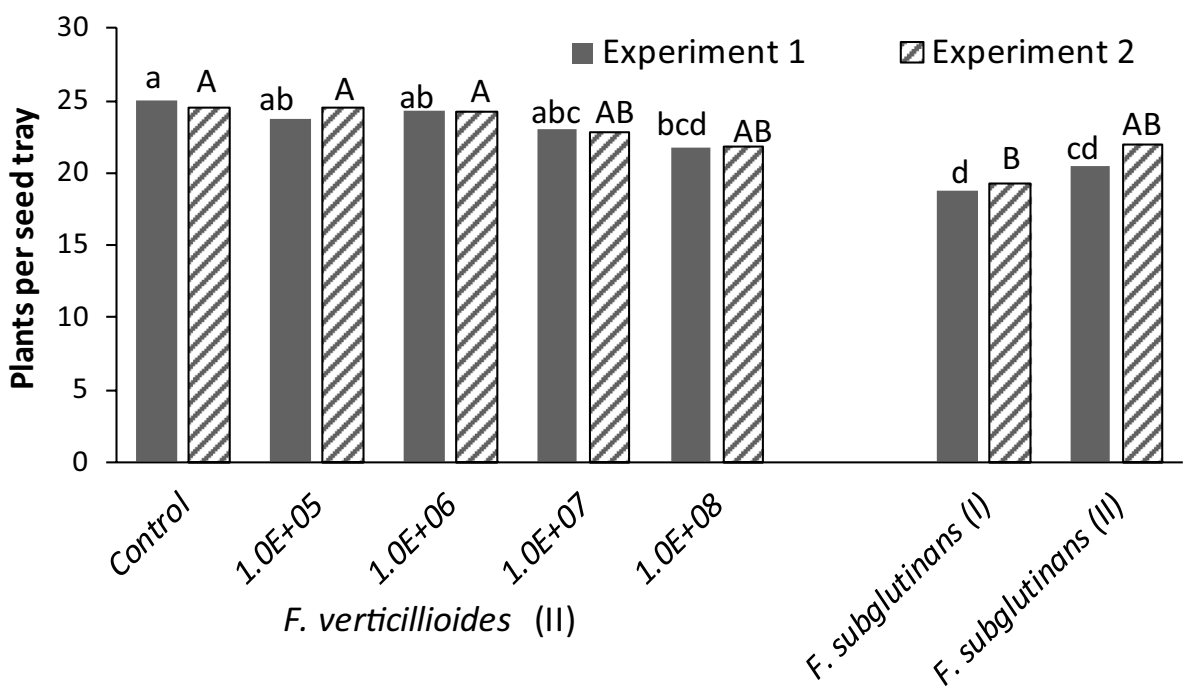

rosea HJS1881 was similarly effective. Of the six strains of Chaetomium included in our study, C. cochliodes, C. globosum and C. ramosissimum were the most effective. A certain level of control was also achieved with the non-pathogenic strain $F$. oxysporum MSA 35 and $F$. solani BBA 64531. For strains Streptomyces antimycoticus FZB 53, Trichoderma asperellum $\mathrm{T} 23$ and T. harzianum T16 anti-Fusarium activity has been reported before (compare Table 1). The microorganism that failed to provide protection included, among others, two strains of the bacterium Lysobacter enzymogenes and the ascomycete Persiciospora moreaui.

Inoculation of the potting substrate with fusaria caused a significant reduction in the plant biomass. Isolates $F$. poae, F. culmorum Fu13 and F. avenaceum To8 reduced the biomass by about half, whereas in potting substrate inoculated with strains $F$. culmorum VIII18 and $F$. graminearum $\mathrm{Ck} 3$ and $\mathrm{Os} 12$ germination was completely inhibited (Fig. 7).

The millet, buckwheat and pearl barley inocula all reduced the plant stand (not shown) and plant biomass in a dose-dependent manner (Fig. 8). However, the results obtained with the millet inoculum were less variable, and the millet inoculum appeared to cause a greater reduction in biomass than the buckwheat and pearl barley inocula.

Compared to untreated seed, treatment with the chemical Thiram reduced the loss caused by $F$. culmorum significantly. Based on biomass, the level of control by Thiram was about $60 \%$ and $45 \%$ in potting substrate with 1 and $3 \%$ inoculum, respectively. 
Fig. 4 Effect of seed inoculation with different concentrations of conidial suspensions of Fusarium verticillioides (I) and two isolates of F. subglutinans $\left(1 \times 10^{7}\right.$ conidia per $\left.\mathrm{ml}\right)$ on biomass of maize seedlings (Means of 2 individual experiments, each with 4 seed trays per treatment and 25 seeds per tray; determined 14 days after sowing). Different letters above bars indicate statistically significant differences between treatments within the experiments $(p \leq 0.05)$

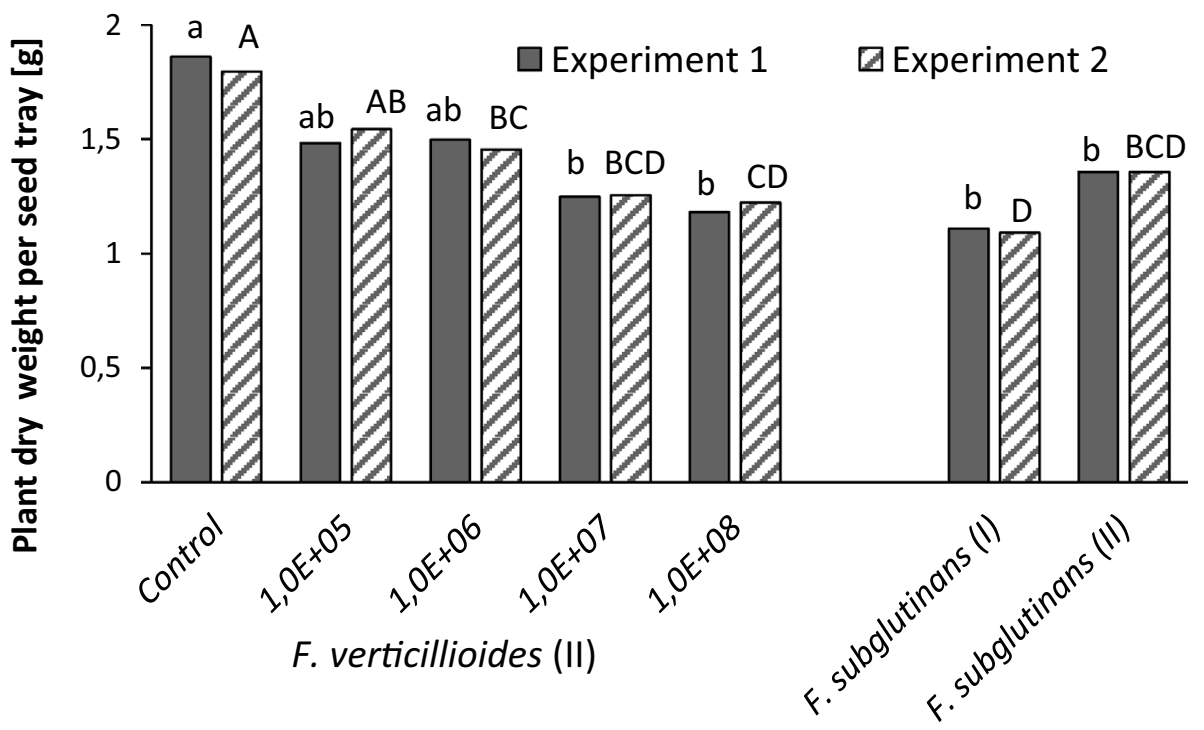

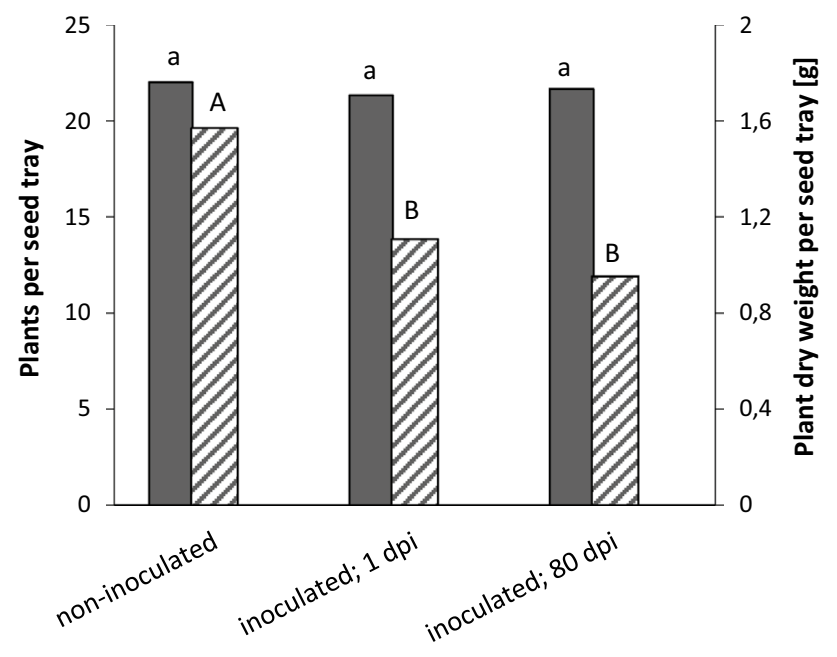

Fig. 5 Effect of storage of maize seed inoculated with Fusarium verticillioides (II) $\left(1 \times 10^{7}\right.$ conidia per $\left.\mathrm{ml}\right)$ on plant stand (solid bars) and plant dry weight (hatched bars). Storage duration after inoculation was 80 days. Included in the experiment were non-inoculated seeds and seeds sown 1 day after inoculation (dpi) (Means of 3 seed trays per treatment and 25 seeds per tray; determined 14 days after sowing). Different letters above bars indicate statistically significant differences between treatments $(p \leq 0.05)$

\section{Discussion}

In this study, fusaria were isolated from maize kernels and their pathogenicity was determined in tests in seed trays. Because the kernels were surface-disinfected before placement on filter paper, it is safe to assume that the isolated fusaria were located in the seed coat or deeper. The species isolated, F. verticillioides, $F$. subglutinans, $F$. cerealis and $F$. poae are all known pathogens of maize causing seedling blight and rots of roots, stalks and cobs (Leslie and Summerell 2006, Dorn et al. 2011, Solorzano and Malvick 2011, Oldenburg et al. 2017, Gromadzka et al. 2019).

In the pathogenicity tests, differences between isolates were nevertheless observed. For example, isolates of $F$. verticillioides and $F$. subglutinans reduced the plant dry weight significantly, whereas the tested isolates of $F$. proliferatum and $F$. poae had only a weak effect. However, due to the low number of isolates employed conclusions regarding the potential of the species to affect germination and to cause seedling diseases are difficult to draw. In a similar study with two isolates each of the species $F$. graminearum, $F$. verticillioides, $F$. oxysporum, $F$. proliferatum, $F$. solani and $F$. subglutinans, most of the isolates were pathogenic to maize seedlings, but a few were not, and aggressiveness of the isolates varied as much within a species as among species (Munkvold and O`Mara 2002). In experiments including different maize varieties and isolates of $F$. verticillioides (reported as $F$. moniliforme), the latter differed in aggressiveness to corn seedlings, but there was no apparent isolate $\mathrm{x}$ cultivar interaction, which indicated a lack of physiological specialization of $F$. verticillioides (Bacon et al. 1994).

Studies with artificial inoculation of seeds of crops other than maize with fusaria commonly used conidial concentrations of $1 \times 10^{5}-1 \times 10^{6}$ per ml (Wilke et al. 2007; Sousa et al. 2008; Imathiu et al. 2010; Maitlo et al. 2016). For the inoculation of maize kernels with $F$. verticillioides, use of concentrations of $1 \times 10^{5}$ (reported as $F$. moniliforme; Galperin et al. 2003) and $1 \times 10^{7}$ conidia per ml, respectively (Pereira et al. 2011) has been reported. In our experiments, concentrations of $1 \times 10^{7}$ and $1 \times 10^{8}$ conidia per ml of $F$. verticillioides caused a higher loss of biomass than $1 \times 10^{5}$ and $1 \times 10^{6}$ conidia per ml. This deviates from a 


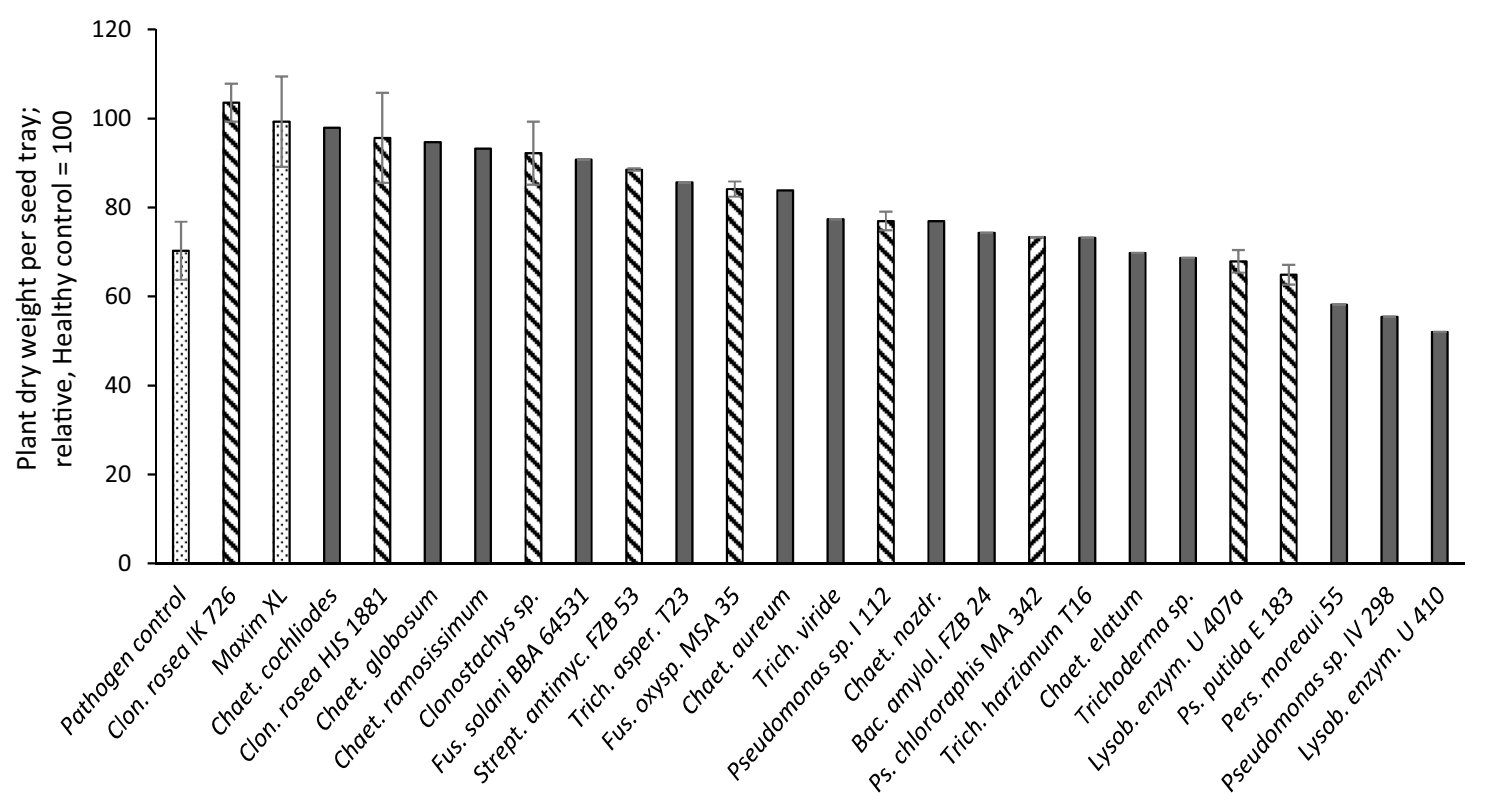

Fig. 6 Efficacy of treatment of maize kernels with different bacteria and fungi against seed-inoculated Fusarium subglutinans (I). Pooled results from altogether 8 experiments. Means and standard deviation of plant dry weight from 2 seed trays, each with 25 seeds each per treatment, in relation to the controls in the respective experiments.
The treatments were tested once (solid bars) or twice (hatched bars). The chemical standard seed treatment Maxim XL, a healthy control and a pathogen control were included in all eight experiments (dotted bars)
Fig. 7 Effect of inoculation of the potting substrate with different fusaria on biomass of maize seedlings (Inoculum: pearl barley, inoculum concentration: $3 \%(\mathrm{w} / \mathrm{v})$. Means of 5 pots with 6 seeds each per treatment; determined 15 days after sowing). Different letters above bars indicate statistically significant differences $(p \leq 0.05)$

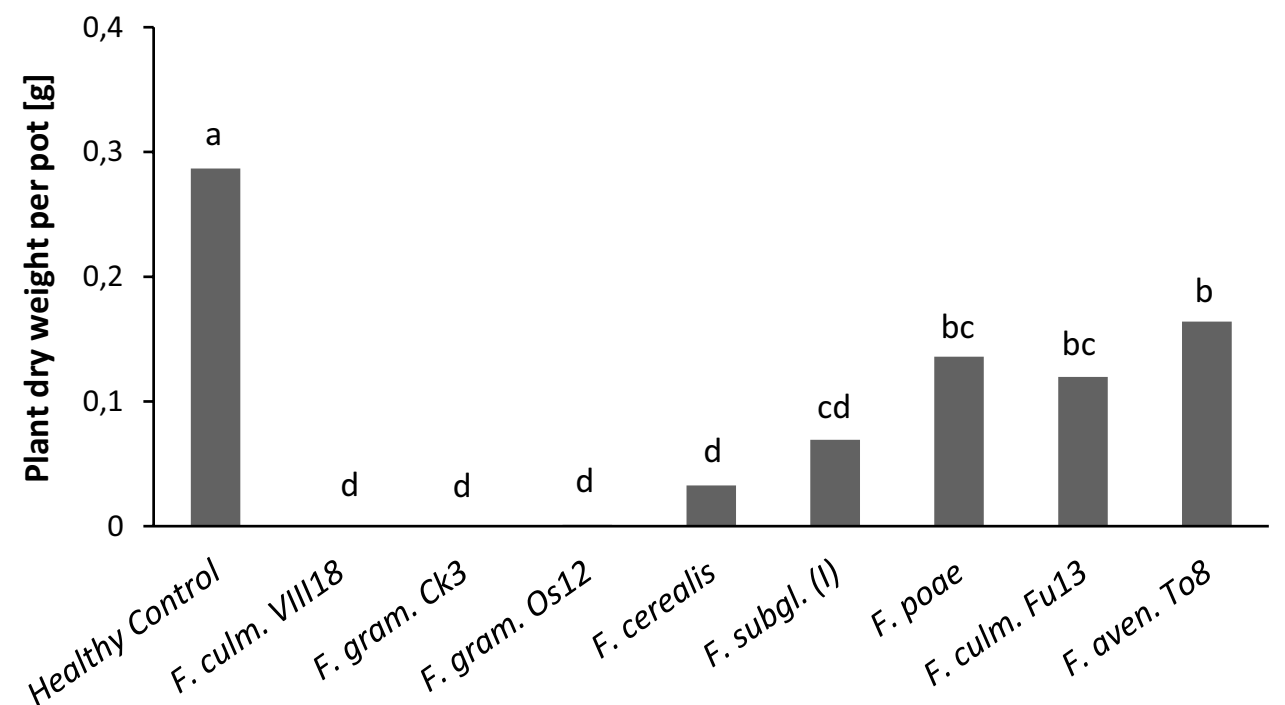

study reporting that identical results were obtained with a wide range of conidial concentrations of $F$. verticillioides. However, the authors reason that mycelia present in the conidial suspensions may have contributed to this result (Bacon et al. 1994, Bacon and Hinton 1996).

Large differences in plant development were also seen when healthy maize kernels were sown in potting substrate inoculated with different fusaria. At the inoculum concentration of 3\%, one isolate of F. culmorum (isolated from wheat kernels) and two of $F$. graminearum (from maize silage) completely halted plant growth. In two follow-up experiments, the loss caused by the same inoculum concentration was lower and could be partially compensated by seed treatment with a chemical fungicide. Of the three substrates tested for the production of inoculum, millet seeds appeared to be preferable. Taken together, the results 
Fig. 8 Effect of inoculation of the potting substrate with F. culmorum VIII18 raised on different substrates on biomass of maize seedlings. In Experiment 2 , two of the treatments included a seed treatment with Thiram. (Means of 3 pots with 6 seeds each per treatment; determined 14 days after sowing). Different letters above bars indicate statistically significant differences $(p \leq 0.05)$

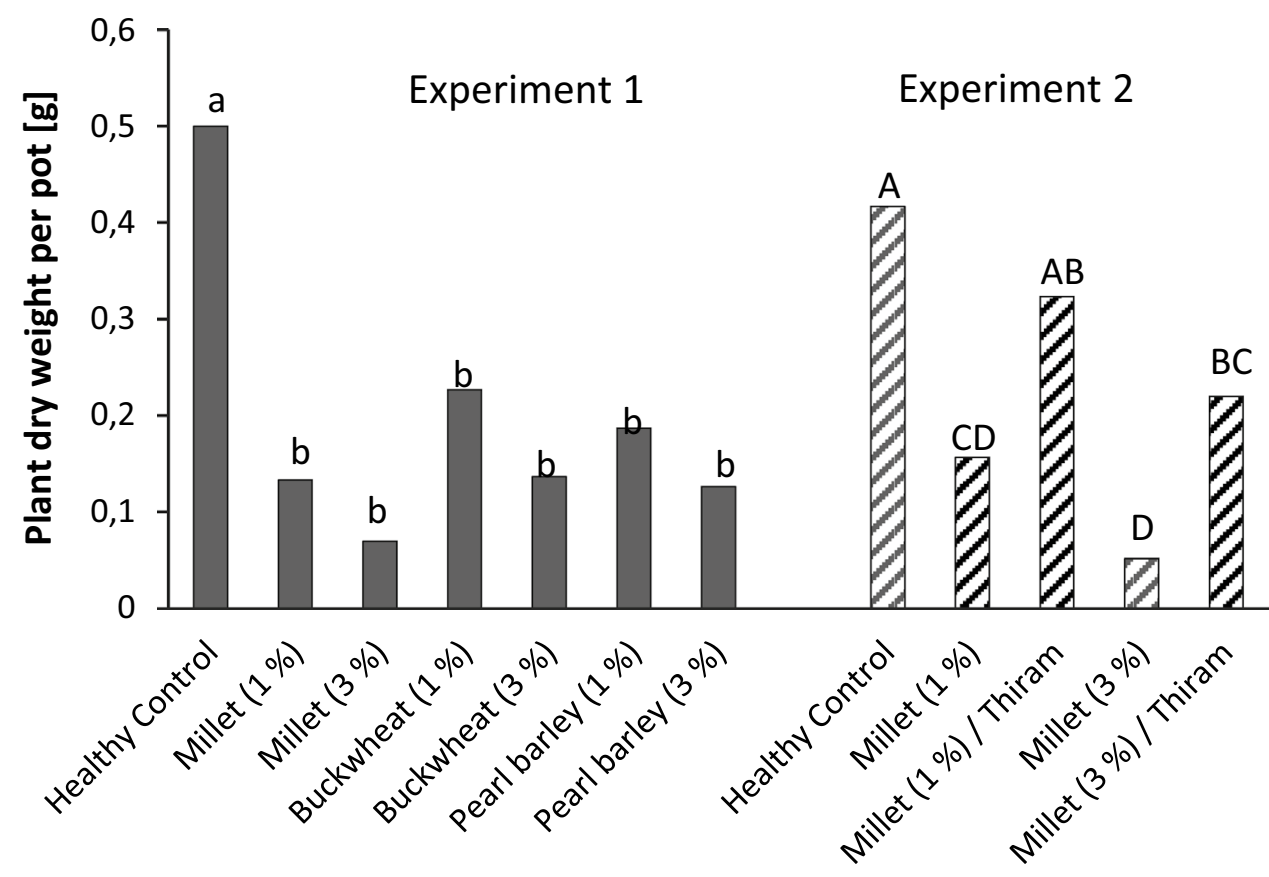

indicate that the chosen experimental setup is suited also for screening seed-applied microbial antagonists for activity against soil-borne fusaria. However, as with other soil-borne pathosystems, maintaining an adequate infection pressure in consecutive experiments is critical for obtaining reproducible results.

In the experiments testing the potential of microorganisms to control seed-borne Fusarium infections, we used inoculation by immersion of the seeds in mixtures of the biocontrol agents and conidia of the pathogen, since sequential application could have let to washing off the inoculum applied first. Co-inoculation of pathogen and antagonist has been also used in other studies (e.g. Pereira et al. 2011). Several reports describe Clonostachys rosea as a fungal antagonist with activity against different plant pathogens (Cota et al. 2009; Hue et al. 2009; Rodríguez et al. 2011). Likewise, we also recorded a high level of control of $F$. subglutinans by the two isolates of $C$. rosea included in our study. Clonostachys rosea IK726 is known as an antagonist of a number of seed-borne fungal pathogens including Fusarium culmorum, Bipolaris sorokiniana and Alternaria spp. (Knudsen et al. 1995; Jensen et al. 2007; Koch et al. 2010; Nygren et al. 2018). Also among the best performing isolates were three isolates of Chaetomium, i.e., C. globosum, C. cochliodes and $C$. ramosissimum. The saprophytic genus Chaetomium comprises a large number of species, some of which are antagonists of plant pathogens (Madbouly and Abdel-Wareth 2020). For C. globosum, it has been reported that the ascospores germinated rapidly and covered the seed coat with a dense mycelium (Hubbard et al. 1982). Surprisingly, seed inoculation with Fusarium solani and $F$. oxysporum MSA also provided protection against co-applied F. subglutinans. The significance of this finding remains to be elucidated in further studies. At present, one can only speculate that mechanisms similar to those responsible for the protection against Fusarium wilt by nonpathogenic strains of F. oxysporum (Alabouvette et al. 2009) may be involved.

Altogether, it appears that some of the tested strains are potentially suited as seed treatments to protect maize against seed-borne fusaria. However, after artificial inoculation the pathogen inoculum is located on the seed surface where it is more exposed to control agents than deeper-seated infections, an important limitation when correlating the results from artificial inoculation with the practical field conditions (Uoti 1979). With this in mind, the results obtained are preliminary and require verification with larger sample numbers and under conditions more closely resembling the agricultural practice, including use of naturally infected seeds. Since seed treatments must control both, seed- and soil-borne fusaria, future work should also include testing against pathogen attack from the soil. For this, the test method developed in this work using inoculation of the potting substrate with fusaria appears suitable.

Acknowledgements Open Access funding provided by Projekt DEAL. Thanks are due to Dan Funck Jensen (Swedish Agricultural University, Uppsala), Monika Gossman (formerly Humboldt University Berlin), Hans-Josef Schroers (Agricultural Institute of Slovenia), Abbas ElHasan (University of Hohenheim, Institute of Phytomedicine), Federico Tinivella (University of Turin) and Wolfgang Maier (JKI, Institute for Epidemiology and Pathogen Diagnostics) for supplying fungal strains. 
Funding The research presented here was for the most part carried out in a joint project between the JKI Institute for Biological Control and Fraunhofer-Institut für Organische Elektronik, Elektronenstrahl- und Plasmatechnik FEP, Dresden. A part of this work was supported by funds of the Federal Ministry of Food and Agriculture (BMEL) based on a decision of the parliament of the Federal Republic of Germany via the Federal Office for Agriculture and Food (BLE).

\section{Compliance with ethical standards}

Conflicts of interest The authors declare that they have no conflict of interest.

Open Access This article is licensed under a Creative Commons Attribution 4.0 International License, which permits use, sharing, adaptation, distribution and reproduction in any medium or format, as long as you give appropriate credit to the original author(s) and the source, provide a link to the Creative Commons licence, and indicate if changes were made. The images or other third party material in this article are included in the article's Creative Commons licence, unless indicated otherwise in a credit line to the material. If material is not included in the article's Creative Commons licence and your intended use is not permitted by statutory regulation or exceeds the permitted use, you will need to obtain permission directly from the copyright holder. To view a copy of this licence, visit http://creativecommons.org/licenses/by/4.0/.

\section{References}

Alabouvette C, Olivain C, Migheli Q, Steinberg C (2009) Microbiological control of soil-borne phytopathogenic fungi with special emphasis on wilt-inducing Fusarium oxysporum. New Phytol 184:529-544

Bacon CW, Hinton DM (1996) Symptomless endophytic colonization of maize by Fusarium moniliforme. Can J Bot 74:1195-1202

Bacon CW, Hinton DM (2007) Potential for control of seedling blight of wheat caused by Fusarium graminearum and related species using the bacterial endophyte Bacillus mojavensis. Biocontrol Sci Technol 17:81-94

Bacon CW, Hinton DM, Richardson MD (1994) A corn seedling assay for resistance to Fusarium moniliforme. Plant Dis 78:302-305

Bressan W, Figueiredo JEF (2005) Biological control of Stenocarpella maydis in maize seed with antagonistic Streptomyces sp. isolates. J Phytopathol 153:623-626

Browne RA, Cooke BM (2005) Resistance of wheat to Fusarium spp. in an in vitro seed germination assay and preliminary investigations into the relationship with Fusarium head blight resistance. Euphytica 141:23-32

Cota LV, Maffia LA, Mizubuti ESG, Macedo PEF (2009) Biological control by Clonostachys rosea as a key component in the integrated management of strawberry gray mold. Biol Control 50:222-230

Dorn B, Forrer HR, Jenny E, Wettstein FE, Bucheli TD, Vogelgsang S (2011) Fusarium species complex and mycotoxins in grain maize from maize hybrid trials and from grower's fields. J Appl Microbiol 111:693-706

El-Hasan A, Schöne J, Höglinger B, Walker F, Voegele RT (2018) Assessment of the antifungal activity of selected biocontrol agents and their secondary metabolites against Fusarium graminearum. Eur J Plant Pathol 150:91-103

Galperin M, Graf S, Kenigsbuch D (2003) Seed treatment prevents vertical transmission of Fusarium moniliforme, making a significant contribution to disease control. Phytoparasitica 31:344-352
Gilardi G, Tinivella F, Gullino ML, Garibaldi A (2005) Seed dressing to control Fusarium oxysporum f.sp. lactucae. J Plant Dis Prot 112:240-246

Gromadzka K, Chełkowski J, Basińska-Barczak A, LalakKańczugowska J (2019) Diversity and mycotoxin production by Fusarium temperatum and Fusarium subglutinans as causal agents of pre-harvest Fusarium maize ear rot in Poland. J Appl Genet 60:113-121

Hörmann V, Gossmann M, Junge H, Büttner C (2010) Morphologische Charakterisierung von Persiciospora moreaui und Melanospora zamiae in Fusarium spp.-Isolaten von Spargel- und Gurkenpflanzen. Julius-Kuhn-Arch 428:412

Hubbard JP, Harman GE, Eckenrode CJ (1982) Interaction of a biological control agent, Chaetomium globosum, with seed coat microflora. Can J Microbiol 28:431-437

Hue AG, Voldeng HD, Savard ME, Fedak G, Tian X, Hsiang T (2009) Biological control of Fusarium head blight of wheat with Clonostachys rosea strain ACM941. Can J Plant Pathol 31:169-179

Imathiu SM, Hare MC, Ray RV, Back M, Edwards SG (2010) Evaluation of pathogenicity and aggressiveness of $F$. langsethiae on oat and wheat seedlings relative to known seedling blight pathogens. Eur J Plant Pathol 126:203-216

Jensen DF, Knudsen IM, Mamarabadi M, Hockenhull J, Jensen B (2007) Development of a biocontrol agent for plant disease control with special emphasis on the near commercial fungal antagonist Clonostachys rosea strain 'IK726'. Australas Plant Pathol 36:95-101

Johnsson L, Hökeberg M, Gerhardson B (1998) Performance of the Pseudomonas chlororaphis biocontrol agent MA 342 against cereal seed-borne diseases in field experiments. Eur J Plant Pathol 104:701-711

Knudsen MB, Hockenhull J, Jensen DF (1995) Biocontrol of seedling diseases of barley and wheat caused by Fusarium culmorum and Bipolaris sorokiniana: effects of selected fungal antagonists on growth and yield components. Plant Pathol 44:467-477

Koch E (1997) Screening of rhizobacteria for antagonistic activity against $P$. ultimum on cucumber and kale. J Plant Dis Prot 104:353-361

Koch E, Löffler I (2009) Partial characterization of the antimicrobial activity of Streptomyces antimycoticus FZB53. J Plant Dis Prot 157:235-242

Koch E, Roberts SJ (2014) Non-chemical seed treatment in the control of seed-borne pathogens. In: Gullino M, Munkvold G (eds) Global perspectives on the health of seeds and plant propagation material. plant pathology in the 21 st century (contributions to the 9th international congress), vol 6. Springer, Dordrecht

Koch E, Kempf HJ, Hessenmüller A (1998) Characterization of the biocontrol activity and evaluation of potential growth-promoting properties of selected rhizobacteria. J Plant Dis Prot 105:567-580

Koch E, Schmitt A, Stephan D et al (2010) Evaluation of non-chemical seed treatment methods for the control of Alternaria dauci and A. radicina on carrot seeds. Eur J Plant Pathol 127:99-112

Leslie JF, Summerell BA (2006) The Fusarium laboratory manual. Blackwell, Oxford

Madbouly AK, Abdel-Wareth MT (2020) The use of Chaetomium taxa as biocontrol agents. In: Abdel-Azeem AM (ed) Recent developments on genus Chaetomium. Springer, Cham, pp 251-266

Maitlo SA, Syed RN, Rustamani MA, Khuhro RD, Lodhi AM (2016) Influence of inoculation methods and inoculum levels on the aggressiveness of Fusarium oxysporum f. sp. ciceris on chickpea and plant growth. Int J Agric Biol 18:31-36

Mancini V, Romanazzi G (2014) Seed treatments to control seedborne fungal pathogens of vegetable crops. Pest Manag Sci 70:860-868

Mao W, Lumsden RD, Lewis JA, Hebbar PK (1998) Seed treatment using pre-infiltration and biocontrol agents to reduce damping-off 
of corn caused by species of Pythium and Fusarium. Plant Dis 82:294-299

Moussart A, Tivoli B, Lemarchand E, Deneufbourg F, Roi S, Sicard G (1998) Role of seed infection by the Ascochyta blight pathogen of dried pea (Mycosphaerella pinodes) in seedling emergence, early disease development and transmission of the disease to aerial plant parts. Eur J Plant Pathol 104:93-102

Mulè G, Susca A, Stea G, Moretti A (2004a) A species-specific PCR assay based on the calmodulin partial gene for identification of Fusarium verticillioides, $F$. proliferatum and $F$. subglutinans. Eur J Plant Pathol 110:495-502

Mulè G, Susca A, Stea G, Moretti A (2004b) Specific detection of the toxigenic species Fusarium proliferatum and $F$. oxysporum from asparagus plants using primers based on calmodulin gene sequences. FEMS Microbiol Lett 230:235-240

Munkvold GP, O’Mara JK (2002) Laboratory and growth chamber evaluation of fungicidal seed treatments for maize seedling blight caused by Fusarium species. Plant Dis 86:143-150

Munkvold GP, White DG (eds) (2016) Compendium of corn diseases (p. 165). APS Press, St. Paul, Minnesota

Nagy E, Moldovan V (2007) The effect of fungicide treatments on wheat common bunt (Tilletia spp.) in Transylvania. Rom Agric Res 24:33-38

Nicholson P, Simpson DR, Weston G, Rezanoor HN, Lees AK, Parry DW, Joyce D (1998) Detection and quantification of Fusarium culmorum and Fusarium graminearum in cereals using PCR assays. Physiol Mol Plant P 53:17-37

Nielsen J (1976) A method for artificial inoculation of oats and barley for seed treatment trials on seedling-infecting smuts. Can Plant Dis Surv 56:114-116

Nygren K, Dubey M, Zapparata A, Iqbal M, Tzelepis GD, Durling MB, Hensen DF, Karlsson M (2018) The mycoparasitic fungus Clonostachys rosea responds with both common and specific gene expression during interspecific interactions with fungal prey. Evol Appl 11:931-949

O`Callaghan M (2016) Microbial inoculation of seed for improved crop performance: issues and opportunities. Appl Microbiol Biotechnol 100:5729-5746

Oldenburg E, Höppner F, Ellner F, Weinert J (2017) Fusarium diseases of maize associated with mycotoxin contamination of agricultural products intended to be used for food and feed. Mycotoxin Res 33:167-182
Pandey A, Palni LMS, Hebbar KP (2001) Suppression of damping-off in maize seedlings by Pseudomonas corrugata. Microbiol Res 156:191-194

Parry DW, Nicholson P (1996) Development of a PCR assay to detect Fusarium poae in wheat. Plant Pathol 45:383-391

Patiño B, Mirete S, González-Jaén MT, Mulé G, Rodríguez MT, Vázquez C (2004) PCR detection assay of fumonisin-producing Fusarium verticillioides strains. J Food Prot 67:1278-1283

Pereira P, Ibáñez SG, Agostini E, Etcheverry M (2011) Effects of maize inoculation with Fusarium verticillioides and with two bacterial biocontrol agents on seedlings growth and antioxidative enzymatic activities. Appl Soil Ecol 51:52-59

Rodríguez MA, Cabrera G, Gozzo FC, Eberlin MN, Godeas A (2011) Clonostachys rosea BAFC3874 as a Sclerotinia sclerotiorum antagonist: mechanisms involved and potential as a biocontrol agent. J Appl Microbiol 110:1177-1186

Solorzano CD, Malvick DK (2011) Effects of fungicide seed treatments on germination, population, and yield of maize grown from seed infected with fungal pathogens. Field Crop Res 122:173-178

Sousa MV, Machado JC, Pfenning LH, Kawasaki VH, Araújo DV, Silva AA, Martini Neto A (2008) Métodos de inoculação e efeitos de Fusarium oxysporum f. sp. vasinfectum em sementes de algodoeiro. Trop Plant Pathol 33:41-48

Turner AS, Lees AK, Rezanoor HN, Nicholson P (1998) Refinement of PCR-detection of Fusarium avenaceum and evidence from DNA marker studies for phenetic relatedness to Fusarium tricinctum. Plant Pathol 47:278-288

Uoti J (1979) Study of control of seed-borne Fusarium in cereals. Ann Agr Fenn 18:149-153

White TJ, Bruns T, Lee S, Taylor JW (1990) Amplification and direct sequencing of fungal ribosomal RNA genes for phylogenetics. In: Innis MA, Gelfand DH, Sninsky JJ, White TJ (eds) PCR protocols: a guide to methods and applications. Academic Press, New York, pp 315-322

Wilke AL, Bronson CR, Tomas A, Munkvold GP (2007) Seed transmission of Fusarium verticillioides in maize plants grown under three different temperature regimes. Plant Dis 91:1109-1152

Publisher's Note Springer Nature remains neutral with regard to jurisdictional claims in published maps and institutional affiliations. 